\title{
Hubungan antara lama menjalani hemodialisis dengan kualitas hidup pasien yang menjalani hemodialisis di Unit Hemodialisis RSUP. Prof. Dr. R. D. Kandou Manado
}

\author{
${ }^{1}$ Moch. T. S. A. Rahman \\ ${ }^{2}$ Theresia M. D. Kaunang \\ ${ }^{2}$ Christofel Elim
}

\author{
${ }^{1}$ Kandidat Skripsi Fakultas Kedokteran Universitas Sam Ratulangi Manado \\ ${ }^{2}$ Bagian Psikiatri Fakultas Kedokteran Universitas Sam Ratulangi Manado \\ Email: abdurrahmanmoch@gmail.com
}

\begin{abstract}
Chronic kidney disease (CKD) results in a decrease in kidney function that is irreversible and requires treatment in the form of a kidney transplant or hemodialysis. The main goal of hemodialysis is to prevent and control uremia, fluid overload, and electrolyte imbalance. Problems that commonly associate hemodialysis patients are physical and psycological stress that affect the quality of life. This study aimed to obtain the relationship between the duration of hemodialyis and the quality of life. This was an observational analytical study with a cross sectional design. The study included all hemodialysis patients in Dahlia and Melati Hemodialysis Unit Prof. Dr. R. D. Kandou Hospital Manado. There were 34 patients that met the inclusion criteria. The results showed that the correlation between the duration of hemodialyis and the quality of life had a p value of 0.579 . Conclusion: The duration of hemodialysis did not correlate significantly with the quality of life of hemodialysis patients.
\end{abstract}

Keywords: The duration of hemodialysis, quality of life.

\begin{abstract}
Abstrak: Gagal ginjal kronik (PJK) mengakibatkan penurunan fungsi ginjal yang ireversibel, yang memerlukan terapi berupa transplantasi ginjal atau hemodialisis. Tujuan utama hemodialisis yaitu mengendalikan uremia, kelebihan cairan dan ketidakseimbangan elektrolit. Permasalahan yang muncul pada pasien hemodialisis ialah masalah fisik, psikologi, perubahan sosial, dan gaya hidup; hal tersebut memengaruhi kualitas hidup pasien. Peneltian ini bertujuan untuk mencari hubungan antara lama menjalani hemodialisis dengan kualitas hidup. Metode penelitian yang digunakan ialah observasional analitik dengan pendekatan potong lintang Penelitian ini melibatkan semua pasien hemodialisis di Unit Hemodialisis Dahlia dan Melati RSUP Prof. Dr. R. D. Kandou Manado yang memenuhi kriteria inklusi yaitu sebanyak 34 orang. Hasil penelitian menunjukkan korelasi antara lama menjalani hemodialisis dengan kualitas hidup dengan nilai $\mathrm{P}=0,579$. Simpulan: Tidak terdapat hubungan antara lama menjalani hemodialisis dengan kualitas hidup pada pasien hemodialisis.
\end{abstract}

Kata kunci: lama menjalani hemodialisis, kualitas hidup.

Hemodialisis merupakan satu tindakan yang bertujuan untuk mengambil zat-zat nitrogen yang bersifat toksik dari dalam darah dan mengeluarkan air yang berlebih. ${ }^{1}$ Tujuan utama hemodialisis menghilangkan gejala yaitu mengendalikan uremia, kelebihan cairan dan ketidakseimbangan elektrolit yang terjadi pada pasien penyakit ginjal kronik. ${ }^{2}$ Dosis hemodialisis yang diberikan umumnya 2 kali dalam seminggu dengan setiap hemodialisis 5 jam atau sebanyak 3 kali seminggu dengan setiap 
hemodialisis selama 4 jam. $^{1}$ Lamanya hemodialisis berkaitan erat dengan efisiensi dan adekuasi hemodialisis, sehingga lama hemodialisis juga dipengaruhi oleh tingkat uremia akibat progresivitas perburukan fungsi ginjalnya dan faktor-faktor komorbiditasnya, serta kecepatan aliran darah dan kecepatan aliran dialisat. ${ }^{1}$ Semakin lama proses hemodialisis, maka semakin lama darah berada diluar tubuh, sehingga makin banyak antikoagulan yang dibutuhkan, dengan konsekuensi sering timbulnya efek samping. ${ }^{1}$

\section{KUALITAS HIDUP}

Kualitas hidup adalah persepsi individu mengenai posisi mereka dalam hidup dalam konteks budaya dan sistem nilai tempat mereka tinggal, dan hubungan dengan standar hidup, harapan, kesenangan, dan perhatian. Hal ini terangkum secara kompleks mencakup kesehatan fisik, status psikologis, tingkat kemandirian, hubungan sosial, dan hubungan pada karakteristik lingkungan mereka. ${ }^{7,8}$

Kualitas hidup merupakan sesuatu yang bersifat subyektivitas dan multidimensi. Subyektivitas, mengandung arti bahwa kualitas hidup hanya dapat ditentukan dari sudut pandang pasien itu sendiri, sedangkan multidimensi bermakna bahwa kualitas hidup dipandang dari seluruh aspek kehidupan seseorang secara holistik meliputi aspek biologis, fisik, psikologis, sosiokultural dan spiritual. $^{9}$ Dukungan spiritual dapat berupa keyakinan yang kuat atau energi positif hal ini dapat membuat seseorang menjadi lebih tenang dan secara emosional pasien dapat menjadi rileks, damai dan perasaan-perasaan positif lain yang sangat memengaruhi kesehatan fisiknya. ${ }^{9}$

Faktor-faktor yang memengaruhi kualitas hidup dibagi menjadi dua bagian. Bagian pertama adalah sosio demografi yaitu jenis kelamin, usia, suku / etnik, pendidikan, pekerjaan dan status perkawinan. Kedua adalah medik yaitu lama menjalani hemodialisis, stadium penyakit, dan penatalaksanaan medis yang dijalani. $^{10}$

Penentuan terjadinya penurunan kualitas hidup atau tidak, berdasarkan hasil pengisian kuesioner WHOQOL-BREF. Kuesioner ini terdiri dari 26 item pertanyaan nomor 1 dan 2 tidak dihitung. Pada tiap pertanyaan jawaban point terendah adalah $1=$ sangat tidak memuaskan, sampai dengan $5=$ sangat memuaskan, kecuali untuk pertanyaan nomor 3, 4, dan 26 karena pertanyaan bersifat negatif maka memiliki jawaban mulai skor $5=$ sangat tidak memuaskan hingga skor $1=$ sangat memuaskan. Skor yang diperoleh adalah 0-100 dan kemudian dihitung dengan rumus : ${ }^{11}$

\section{METODE PENELITIAN}

Penelitian ini bersifat observational analitik dengan menggunakan pendekatan potong lintang. Populasi penelitian adalah seluruh pasien hemodialis di kota Manado. Populasi terjangkau yaitu pasien hemodialisis yang menjalani terapi di unit hemodialisis RSUP. Dr.RD. Kandou Manado.Sampel yang menjadi subjek penelitian berdasarkan kriteria yang sudah ditetapkan dengan teknik pengambilan sampel yaitu purposive. Kriteria inklusi pada pengambilan sampel, yaitu pasien dengan penyakit ginjal kronik yang datang untuk menjalani hemodialisis di RSUP. Prof. Dr. R. D. Kandou Manado, menikah sah dan datang bersama pasangan, berumur $<60$ tahun, bersedia menjadi responden. Penelitian ini menggunakan kuesioner data demografi dan kusioner World Health Organization Quality of Life (WHOQOLBREF) terdiri dari 26 item pertanyaan nomor 1 dan 2 tidak dihitung. Pada tiap pertanyaan jawaban point terendah adalah 1 = sangat tidak memuaskan, sampai dengan 5 = sangat memuaskan, kecuali untuk pertanyaan nomor 3, 4, dan 26 karena pertanyaan bersifat negatif maka memiliki jawaban mulai skor $5=$ sangat tidak memuaskan hingga skor $1=$ sangat memuaskan. Skor yang diperoleh adalah 0100 dan kemudian dihitung dengan rumus. ${ }^{11}$ 


\section{HASIL PENELITIAN}

Penelitian ini dilakukan di unit hemodalisis Dahlia dan Melati RSUP. Prof. Dr. R. D. Kandou Manado. Tabel 1 memperlihatkan subjek penelitian terdiri dari 30 laki-laki $(88,2 \%)$ dan 4 perempuan $(11,8 \%)$ dari 34 subjek penelitian

Tabel. 1 Distribusi Jenis Kelamin Subjek Penelitian

\begin{tabular}{ccc}
\hline Kategori & Frekuensi & $(\%)$ \\
\hline Jenis laki-laki & 30 & 88,2 \\
Kelamin Perempuan & 4 & 11,8 \\
Total & 34 & 100,0 \\
\hline
\end{tabular}

Tabel 2 menunjukkan bahwa subjek penelitian memiliki variasi umur berkisar 28-59 tahun dengan persentase terbanyak pada umur 48 tahun yaitu sebanyak 5 orang $(14,7 \%)$.

Tabel 2. Distribusi Usia Subjek Penelitian

\begin{tabular}{cccc}
\hline Kategori & & Frekuensi & (\%) \\
\hline & 28 & 1 & 2,9 \\
& 31 & 1 & 2,9 \\
& 32 & 1 & 2,9 \\
& 33 & 1 & 2,9 \\
& 36 & 1 & 2,9 \\
& 40 & 3 & 8,8 \\
& 41 & 2 & 5,9 \\
Usia & 43 & 1 & 2,9 \\
& 44 & 1 & 2,9 \\
& 45 & 1 & 2,9 \\
& 46 & 1 & 2,9 \\
& 47 & 1 & 2,9 \\
& 48 & 5 & 14,7 \\
& 50 & 1 & 2,9 \\
& 51 & 1 & 2,9 \\
& 53 & 1 & 2,9 \\
& 54 & 1 & 2,9 \\
& 55 & 1 & 2,9 \\
& 56 & 1 & 2,9 \\
& 57 & 1 & 2,9 \\
& 58 & 4 & 11,8 \\
& 59 & 3 & 8,8 \\
& Total & 34 & 100,0 \\
\hline
\end{tabular}

Tabel 3 menunjukkan bahwa distribusi kualitas hidup berdasarkan jenis kelamin, didapatkan 11 orang dengan kualitas hidup baik, 19 orang dengan kualitas hidup kurang baik untuk jenis kelamin laki-laki, untuk janis kelamin perempuan didapatkan 1 orang dengan kualitas hidup baik dan 3 orang kualitas hidup buruk

Tabel 3. Distribusi Kualitas Hidup Berdasarkan Jenis Kelamin

\begin{tabular}{ccccc}
\hline \multirow{2}{*}{ Kategori } & \multicolumn{3}{c}{ Kualitas Hidup } & \multirow{2}{*}{ Total } \\
& Baik & Buruk & \\
\hline Jenis & Laki-Laki & 11 & 19 & 30 \\
Kelamin Perempuan & 1 & 3 & 4 \\
\multicolumn{2}{c}{ Total } & 12 & 22 & 34 \\
\hline
\end{tabular}

Tabel 4 menunjukkan bahwa distribusi kualitas hidup berdasarkan lama menjalani hemodialisis, dari 34 orang didapatkan 7 orang dengan kualitas hidup baik, 15 orang dengan kualitas hidup buruk yang lama menjalani HD lebih dari 6 bulan, dan lama menjalani HD kurang dari 6 bulan didapatkan 5 orang dengan kualitas hidup baik dan 7 orang dengan kualitas hidup buruk.

Tabel 4. Distribusi Kualitas Hidup Berdasarkan Lama Menjalani Hemodialisis

\begin{tabular}{ccccc}
\hline \multirow{2}{*}{ Kategori } & \multicolumn{4}{c}{ Kualitas hidup } \\
Baik & Buruk & Total \\
\hline Lama & $>6$ & 7 & 15 & 22 \\
Menjalani & bln & & & \\
Hemodialisis & $<6$ & 5 & 7 & 12 \\
Totn & 5 & 12 & 22 & 34 \\
\hline
\end{tabular}

Pada Tabel 5 dapat dilihat bahwa korelasi lama menjalani hemodialisis dengan kualitas hidup memiliki nilai signifikan 0,579 yang berarti hubungan antara kedua variabel tidak signifikan.

Tabel 5. Uji Korelasi Lama Menjalani Hemodialisis dengan Kualitas Hidup

\begin{tabular}{clc}
\hline \multicolumn{2}{c}{ Correlations } & $\begin{array}{c}\text { Kualitas } \\
\text { hidup }\end{array}$ \\
\hline Lama HD & $\begin{array}{l}\text { Pearson } \\
\text { Correlation } \\
\text { Sig. (2- } \\
\text { tailed) }\end{array}$ &,- 098 \\
\end{tabular}




\section{BAHASAN}

Berdasarkan hasil penelitian yang dilakukan pada 34 subjek penelitian yang menjalani hemodialisis, menunjukan bahwa subjek penelitian yang berjenis kelamin laki-laki memiliki jumlah lebih banyak yaitu 30 orang $(88,2 \%)$ dibandingkan dengan jenis kelamin perempuan yaitu 4 orang $(11,8 \%)$. Penelitian ini didukung oleh penelitian yang dilakukan Sofiana pada tahun 2010 tentang analisis faktor-faktor yang berhubungan dengan kualitas hidup pasien penyakit ginjal kronik yang menjalani hemodialisis, dari 95 orang terdapat 50 orang $(52,6 \%)$ adalah jenis kelamin laki-laki dan sisanya 45 orang $(47,4 \%)$ adalah perempuan dan penelitian yang dilakukan oleh Zaynab dkk pada tahun 2011 tentang hubungan antara depresi dan kualitas hidup pada pasien hemodialisis, dari 171 orang terdapat 95 orang (55,6 \%) janis kelamin laki-laki dan 76 orang $(44,4 \%)$ jenis kelamin perempuan. $^{10,12}$ Pada dasarnya dari beberapa literatur dijelaskan bahwa pasien penyakit ginjal kronik tidak dipengaruhi oleh jenis kelamin, antara laki-laki dan perempuan memiliki resiko yang sama untuk menderita penyakit ginjal kronis. Berdasarkan hasil penelitian kategori usia terbanyak usia 47-59 tahun dan di ikuti dengan usia 28-46 tahun. Penelitian ini sejalan dengan penelitian yang dilakukan oleh Rustina pada tahun 2012 tentang gambaran tingkat depresi pada pasien gagal ginjal kronik yang menjalani hemodialisis di RSUD Dr. Soedarso Pontianak yang memiliki kisaran usia terbanyak 45-60 tahun. $^{13}$ Usia tersebut merupakan usia produktif sehingga dengan melakukan hemodialisis diharapkan pasien dapat beraktivitas dengan baik dan dapat meningkatkan kualitas hidup dan pada usia produktif pasien terpacu untuk sembuh, mempunyai harapan hidup yang tinggi dan sebagai tulang punggung keluarga. ${ }^{7}$

Berdasarkan hasil penelitian didapatkan (36,7\%) dengan kualitas hidup baik, (63,3\%) dengan kualitas hidup buruk untuk jenis kelamin laki-laki, untuk janis kelamin perempuan didapatkan (25\%) dengan kualitas hidup baik dan (75\%) kualitas hidup buruk.

Dari hasil penelitian ini persentase kualitas hidup buruk lebih banyak perempuan dibandingkan pada laki-laki. Berdasarkan hasil penelitian didapatkan distribusi kualitas hidup berdasarkan lama menjalani hemodialisis, dari 34 orang didapatkan 7 orang $(31,9)$ dengan kualitas hidup baik, 15 orang (68,1\%) dengan kualitas hidup buruk yang lama menjalani HD lebih dari 6 bulan, dan lama menjalani HD kurang dari 6 bulang didapatkan 5 orang $(41,7 \%)$ dengan kualitas hidup baik dan 7 orang (58,3\%) dengan kualitas hidup buruk. Dari hasil penelitian ini presentase kualitas hidup buruk lebih banyak pada subjek penelitian yang menjalani HD lebih dari 6 bulan $(68,1 \%)$ dibandingkan dengan subjek penelitian yang menjalani HD kurang dari 6 bulan (56,3\%).

Berdasarkan hasil penelitian dapat dilihat bahwa korelasi lama menjalani hemodialisis dengan kualitas hidup memiliki nilai signifikan 0,579 yang berarti hubungan antara kedua variebel tidak signifikan dengan demikian dapat disimpulkan bahwa tidak terdapat hubungan antara lama menjalani hemodialisis dengan kualitas hidup.

Kelemahan penelitian ini yaitu jumlah sampel yang sedikit, hal ini disebabkan karena waktu yg relatif singkat dalam pengumpulan sampel dan beberapa pasien dalam kondisi tidak baik. Tempat penelitian yang dilakukan di unit hemodialisis RSUP. Dr. RD. Kandou Manado dan proses wawancara ditempat yang sama, sehingga suasana kurang memiliki privasi dan mempengaruhi jawaban responden. Kondisi pasien saat diwawancara terlihat terburu-buru sehingga kurang berkonsentrasi dalam menjawab pertanyaan, hal ini terjadi karna kebanyakan pasien memilih tidur atau istirahat saat melakukan hemodialisis.

\section{SIMPULAN}

Berdasarkan hasil penelitian dan bahasan dapat disimpulkan bahwa tidak terdapat hubungan bermakna antara lama 
menjalani hemodialisis dengan kualitas hidup.

\section{SARAN}

Perlu dilakukan penelitian lebih lanjut dengan waktu yang lebih lama untuk melihat apakah ada hubungan antara lama hemodialisis dengan kualitas hidup. Diperlukan varisasi penelitian dalam hal hubungan antara kecemasan, depresi dengan kualitas hidup pada pasien hemodialisis.

\section{DAFTAR PUSTAKA}

1. Pranoto I. Hubungan antara lama hemodiaisis dengan terjadinya pendarahan intra serebral. Diakses 25 September 2014. Tersedia dari: http://core.ac.uk/download/files/478/1 2351930.pdf

2. Farida A. Pengalaman klien hemodialisis terhadap kualitas hidup dalam konteks asuhan keperawatan di RSUP Fatmawati Jakarta. Diakses 27 September 2014. Tersedia dari: http://lib.ui.ac.id/file?file=digital/137 288-T-Anna\%20Farida.pdf

3. Riset Kesehatan Dasar. Prevalensi dan insidensi penyakit ginjal kronik di Indonesia. Diakses 04 Oktober 2014. Tersedia dari: http://www.depkes.go.id/resources/do wnload/general/Hasil\%20Riskesdas\% 202013.pdf.

4. Lukman N, Kanine E, Wowiling F. Hubungan tindakan hemodialisis dengan tingkat depresi klien penyakit ginjal kronik di RSUP Prof. Dr. RD. Kandou Manado. Diakses 04 Oktober 2014. Tersedia dari: http://download.portalgaruda.org/artic le.php?article $=140993 \&$ val $=5798$

5. Santoso MB. Quality of life in regular hemodialysis patient with and without health insurance in Bandung city. Diakses 07 Oktober 2014. Tersedia dari:

http://media.unpad.ac.id/thesis/22012 0/2010/220120100036_c_3876.pdf

6. Santos IDR, Danaga AR, Oliveira LVF, et al. Cardiovascular risk and mortality in end-stage renal disease patients undergoing dialysis: sleep study, pulmonary function, respiratory mechanics, upper airway collapsibility, autonomic nervous activity, depression, anxiety, stress and quality of life: a prospective, double blind, randomized controlled clinical trial. BMC Nephrol. 2013; 14: 215.

7. Istanti PY. Hubungan antara masukan cairan dengan interdialytic weight gains (idwg) pada pasien chronic kidney diseases di unit hemodialisis RS. Pku Muhammadiyah Yogyakarta. Diakses 16 Januari 2015. Tersedia dari:

http://lib.ui.ac.id/file?file=digital/125 543-TESIS0580\%20Yun\%20N09fFaktor-faktor-Analisis.pdf

8. Joshi DV. Quality of life in end stage renal disease patients. World J Nephrol. 2014;3(4):308-16.

9. Riyanto W. Hubungan antara penambahan berat badan di antara dua waktu hemodialisis (interdialysis weight gain $=i d w g$ ) terhadap kualitas hidup pasien penyakit ginjal kronik yang menjalani terapi hemodialisis di Unit hemodialisa ip2k RSUP Fatmawati Jakarta [Tesis]. Jakarta: Universitas Indonesia; 2014.

10. Nurcahyati S. Analisis faktor-faktor yang berhubungan dengan kualitas hidup pasien penyakit ginjal kronik yang menjalani hemodialisis di Rumah Sakit Islam Fatimah Cilacap dan Rumah Sakit Umum Banyumas. Diakses 23 September 2014. Tersedia dari:

http://repository.usu.ac.id/bitstream/1 23456789/43193/2/Reference.pdf.

11. Diaz FM, Ferrer AR, Cascales FR. "Sexual functioning and quality of life of male patients on hemodialysis.” Nephrologia Journal. 2006;26(4):453-8.

12.Sudigdo S, Sofyan I. Dasar-dasar metodologi penelitian klinis. Jakarta: Sagung Seto, 2011; p. 4.

13.World Health Organization Quality of Life. Indonesian WHOQOL-BREF. Diakses 08 Oktober 2014 Tersedia dari:

http://www.who.int/substance_abuse/ research_tools/en/indonesian_whoqol .pdf. 